\section{Behaviour of Polyethylene Glycol on Dialysis and Gel-filtration}

Potyethylene glycol is now widely used for eoncontrating protoin solutions by dialysis. We have used the material of molecular weight 15,000 (L. Light and Co., Ltd., Colnbrook, England) and have found that it ponetrates dialysis sacs to an approciable extent.

$100 \mathrm{ml}$. distilled water was dialysod against polyethylene glycol in a sac of 24/32" "Visking' tubing until the sac was apparently empty. The contents of tho sac were rinsed out with distilled water and a residue of $27 \mathrm{mg}$ was obtained on freeze-drying.

Although it seemed likely that this material must bo of low molecular woight and would thorofore separate from protoins on gel-filtration on 'Sephadex $G-100$ ' (Pharmacia, Uppsala, Swodon), this turns out not to be so. Fig. 1 shows the olution curvos obtainod with $50 \mathrm{mg}$ polyethylene glycol (mol. wt. 15,000) and of $27 \mathrm{mg}$ of the material which passed into the dialysis sac abovo. The column was propared and eluted with 0.02 M-phosphate buffer $p \mathrm{H} \quad 6 \cdot 9$, and the volumo in which the sample was appliod was $5 \mathrm{ml}$. in oach case. 'The polyothylene glycol in tho effluent was estimated by heating I-rnl. samples, diluted if necossury, for $30 \mathrm{~min}$ at $100^{\circ}$ with $1.0 \mathrm{ml} .0 .2 \mathrm{~N} \mathrm{KMnO}_{4}$ and $1.0 \mathrm{ml} .2 \mathrm{~N} \mathrm{H}_{2} \mathrm{SO}_{4}$ and titrating with thiosulphato the iodine liborated on addition of excess KI to the coolod reaction mixtures. A standard curvo was prepared relating decreaso of the thiosulphate titre to woight of polyelhylone glycol. The recovery of polyethylono glycol from both columns appoared to be 110 por cent.

Fig. 1 also shows the olution curves obtained in separato oxperiments on the same column for about $18 \mathrm{mg}$ human haemoglobin (mol. wt. 68,000 ) run in $0.02 \mathrm{M}$ phosphate buffer, $p \mathrm{H} \quad 6.9$, and applied in $2 \mathrm{ml}$. of the same buffer, and for about $30 \mathrm{mg}$ pepsin $\mathrm{C}$ (= para popsin II, mol. wt. 40,700 (ref. 1)), run in 0.1 M acctate,
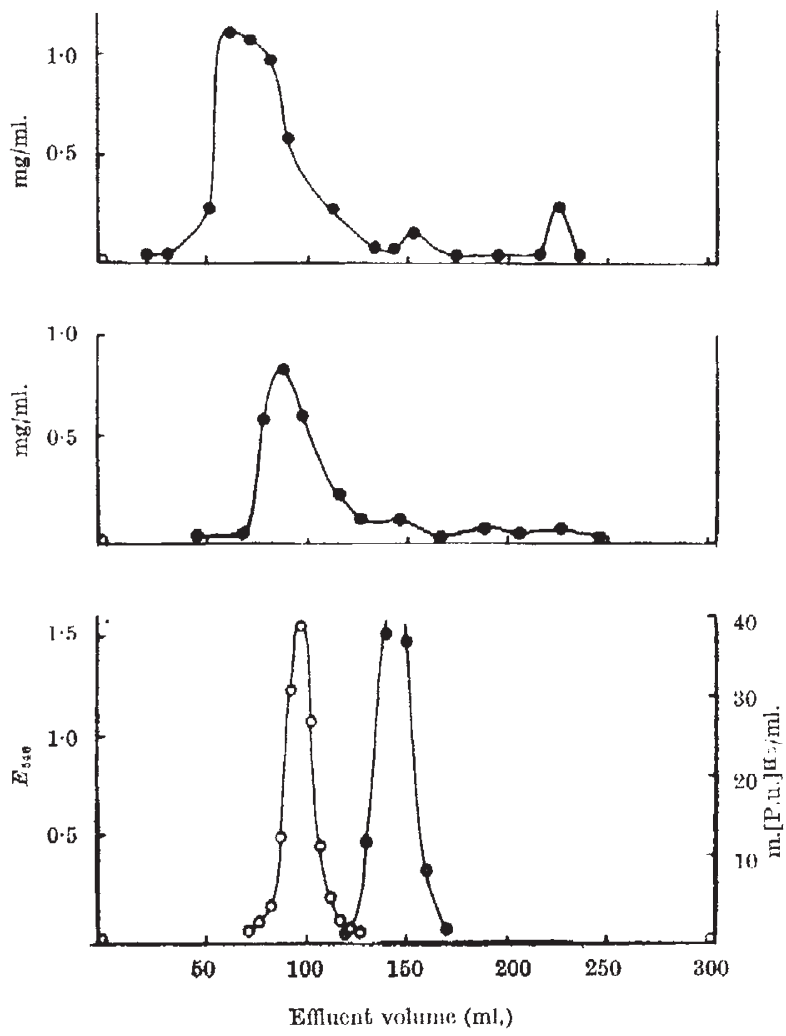

Fig. 1. Gel filtration on 'Sephadex $G-100$ '. Column $2 \cdot 3 \mathrm{~cm} \times 40 \mathrm{~cm}$ Lpper, unfraetionated molyethylene glyeol; middle, polyethylene glycol from diatysis sac; lower, hacmoglobin $O$ and pelsin $C$ $p H 5 \cdot 6$, and applied in $20 \mathrm{ml}$. of the samo buffer. The haomoglobin in tho effluent was estimated by its extinetion at $540 \mathrm{~m} \mu$ and the popsin $\mathrm{C}$ by its proteolytic activity against haernoglobin.

It is seen that the fraction of the polyethylene glycol which passed the dialysis mombrane has omergod in a slightly larger elution volume than the whole polyothyleno glycol, indicating that it is a fraction of slightly smallor molecular size.

Both samples of the polyethylene glycol, however, have omerged in a volume considerably smaller than that at which the protein of molocular weight 40,700 is found and at about the same volume as the protein of molecular weight 68,000 .

It is possible that polyethylene glycol exists in aqueous solution as a random coil and thus exhibits a larger effective molecular size than a protein of greater molecular woight in gel filtration, but this leaves unexplained the passage of the material through the dialysis membrane. Whatevor the explanation of the phenomenon, it is apparont that gol-filtration is not necessarily a suitablo means of separating polyethylene glycol from proteins of moderate molecular weight. Jon-oxchange chromatography may be usod for this purpose-We havo found that, us expoctod, polyethylen glycol is not retarded on columns of diethylaminoothyl-or carboxymethyl-colluloso at $p \mathrm{H} 6 \cdot 9$.

\section{A. P. RyLE}

Department of Biochemistry,

University of Edinburgh.

${ }^{1}$ Ryle, A. P., and Porter, R. R., Biochem. J., 73, 75 (1959).

\section{Onuphic Acid-A Sugar Phosphate Polymer from the Tube of Hyalinoecia tubicola}

ALтнолGH sugar phosphato polymers are present in bacterial cell walls ${ }^{1}$ and phosphorylated polysaccharides are produced by certain yeasts ${ }^{2}$, reports of macromolecules composed of carbohydrate and phosphate in higher animals have been confined to the ribose phosphate backbone of the nucleic acids. During an investigation of the nature of skeletal structures in the invertebrates, however, it has been observed ${ }^{3}$ that in the tubes of the marine worm Hyalinoecia tubicola tho phosphate is not present as inorganic salt but is closoly associated with carbohydrates.

H. tubicola lives inside a tough, portablo, quill-like tube made of a light, translucont substance which contains appreciablo quantities of magnesium, calcium and phosphorus. In 1882 , Schmiedeberg ${ }^{4}$ analysed the tubes of Onuphis (now Hyalinoecia) tubicola and found ash 37.5 , $\mathrm{Mg} 5 \cdot 9$, Ca 2.4 and $\mathrm{P} 9.5$ per cent. He suggested that the tube consisted of a carbohydrate substance 'onuphin', albuminoid and the acid phosphates of calcium and unasnosium, and ho commented that it was difficult to propare onuphin free from phosphate without degrading it. Later, in a survoy of inorganic deposits in the invertebratcs, Clarke and Wheelers reported quantities of magnesium, calcium and phosphorus in $H$. artifex similar to those found from $H$. tubicola, and they explained the discrepancies in the proportions of basos to acid by assuming that the phosphate might bo present as metaphosphato or polyphosphate.

Our analyses for ash $(37.2$ per cent) and for phosphorus (9.3 per cent) in the washed and dried tubes of $H$. tubicola agree closely with those of Schmiedeberg, but we have been unable to establish the presence of any orthophosphate, motaphosphate or polyphosphato in the supernatant after acid demineralization. Tho X-ray diffraction pattern of whole tubes contains two broad diffuse rings only; no well-defined, oriented or continuous reflexions suggesting crystalline salts have been observed.

After demineralization in $1 \mathrm{~N} \mathrm{HCl,} \mathrm{tho} \mathrm{tube} \mathrm{swolls} \mathrm{to}$ a gelatinous mass in which, aftor washing, only a small 